\title{
PERSEPSI PETANI TERHADAP STRATEGI KOMUNIKASI PENYULUH DALAM PEMANFAATAN MEDIA INFORMASI DI ERA DIGITAL
}

\author{
Farmer's Perception of Communication Strategies in the Use of Information \\ Media in the Digital Era
}

\author{
Selly Oktarina ${ }^{1}$, Nukmal Hakim ${ }^{2}$, Anna Gustina Zainal ${ }^{3}$ \\ ${ }^{1}$ Universitas Sriwijaya, Palembang \\ ${ }^{2}$ Universitas Sriwijaya, Palembang \\ ${ }^{3}$ Universitas Lampung, Kota Bandar Lampung
}

E-mail: sellymus@yahoo.com

\begin{abstract}
The digital age has brought changes to both farmers and extension workers. In carrying out communication activities in the diffusion of innovations, an appropriate communication strategy is needed, so that the message is easily understood by farmers and facilitates the development of farmer groups. This paper is the result of a study that aims to describe farmers 'perceptions of instructor communication strategies in utilizing information media and measuring farmers' communication actions in the application of rice cultivation to support food security. The research location is in Sirah Pulau Padang Village, Ogan Komering Ilir Regency, South Sumatra. The research method used was a survey with a purposive sampling method for six farmer groups that carried out rice cultivation, a sample of 30 farmers. Interviews were conducted with questionnaires as primary data, while secondary data was obtained from the related institutions. Data analysis to measure farmers' perceptions of instructor communication strategies and communication actions of farmers in rice cultivation was carried out by calculating scores. The results showed that the communication strategies used by extension agents were positively perceived by farmers. Likewise, the communication actions of farmers in rice cultivation are high. In particular, the authors review communication strategies that can be implemented so that farmers can take communication actions in rice cultivation, in supporting food security in the digital era and several important recommendations are delivered.
\end{abstract}

Keywords: digital, information, communication, perception, strategy

ABSTRAK
Era digital telah membawa berbagai perubahan baik pada diri petani maupun penyuluh.
Dalam melakukan aktivitas komunikasi dalam difusi inovasi sangat dibutuhkan strategi
komunikasi yang tepat, agar pesan mudah dipahami oleh petani dan mempermudah dalam
melakukan pembinaan kelompok tani. Makalah ini merupakan hasil penelitian yang
bertujuan untuk mendeskripsikan persepsi petani terhadap strategi komunikasi penyuluh
dalam pemanfaatan media informasi dan mengukur tindakan komunikasi petani dalam
penerapan budidaya padi dalam menunjang ketahanan pangan. Lokasi penelitian berada di
Desa Sirah Pulau Padang, Kabupaten Ogan Komering Ilir Sumatera Selatan. Metode
penelitian yang digunakan adalah survey dengan metode penarikan contoh secara sengaja
(purposive sampling) terhadap enam kelompok tani yang melakukan budidaya padi,
sampel berjumlah 30 orang petani. Wawancara dilakukan dengan kuesioner sebagai data
primer, sedang data sekunder diperoleh dari instasi terkait. Analisis data untuk mengukur
persepsi petani terhadap strategi komunikasi penyuluh dan tindakan komunikasi petani
dalam budidaya padi dilakukan dengan perhitungn skor. Hasil penelitian menunjukkan
bahwa strategi komunikasi yang digunakan penyuluh dipersepsi positif oleh petani.
Demikian juga, tindakan komunikasi petani dalam budidaya padi tergolong tinggi. Secara 
khusus, penulis mengulas strategi komunikasi yang dapat diterapkan sehingga petani dapat melakukan tindakan komunikasi dalam budidaya padi, dalam menunjang ketahanan pangan di era digital dan beberapa rekomendasi penting disampaikan.

Kata kunci: digital, informasi, komunikasi, persepsi, strategi

\section{PENDAHULUAN}

Indonesia merupakan negara agraris dimana sebagian besar masyarakatnya bekerja pada sektor pertanian. Selama ini, pemerintah sudah banyak membuat program pembangunan untuk kemajuan masyarakat khususnya bidang pertanian. Program-program tersebut sudah didiseminasikan ke masyarakat di seluruh nusantara yang dianggap cocok untuk dilaksanakan. Berbagai program pemerintah diupayakandalam mewujudkan ketahanan pangan, menurut Dewan Ketahanan Pangan (2006) menyatakan bahwa ketahanan pangan akan terwujud apabila tersedianya pangan yang cukup dan dapat diakses.

Untuk mewujudkan ketahanan pangan tersebut,maka pentingnya peran penyuluh dalam meningkatkan kapasitas petani agar petani terus konsisten meningkatkan produksi padinya. Dimana kita ketahui bahwa beras merupakan pangan pokok bangsa Indonesia sehingga harus selalu dijaga ketersediaannya dalam mewujudkan lumbung pangan keluarga maupun nasional.

Lahan rawa lebak merupakan lahan yang berpotensi untuk terus dimanfaatkan, karena seiring perkembangan zaman sudah banyak teknologi yang dapat diterapkan pada lahan rawa lebak agar dapat menjadi produktif. Di Sumatera Selatan terdapat sekitar 2 juta lahan rawa lebak potensial untuk pertanian dan perikanan,akan tetapi belum dimanfaatkan secara optimal dan hanya ditanami padi dengan produksi yang rendah. Peningkatan produksi padi diharapkan dapat meningkatkan pendapatan dan menunjang swasembada pangan (Djafar, 1992 dalam Suwignyo dkk, 2008).

Peningkatan produksi petani erat kaitannya dengan adanya peran penyuluh, selain kemampuan yang dimiliki petani itu sendiri. Seiring dengan perkembangan teknologi maka penyuluh dan petani dituntut harus melek terhadap teknologi, dimana penyuluh dapat memanfaatakan berbagai media sesuai kebutuhan di era digital. Hal ini juga tidak menutup kemungkinan bagi petani untuk bersifat kosmopolit, dimana mereka memiliki kemampuan untuk mencari informasi di luar sistem maupun pemanfaatan teknologi seperti internet.

Pemanfaatan informasi di era digital dapat diakses oleh siapa saja, tidak terkecuali penyuluh. Penyuluh selalu membutuhkan inovasi dari berbagai instansi dimana salah satu media yang dapat diakses saat ini adalah internet melalui cyber extension. Menurut Sumardjo dkk (2010) menyatakan bahwapenyuluh sering dihadapkan pada kesenjangan inovasi pada saat berperan sebagai pendamping petani dalam membantu pemecahan permasalahan. Aplikasi teknologi informasi melalui sarana komputer maupun telepon seluler (handphone-hp) dalam implementasi cyber ekstension di beberapa negara dapat berfungsi untuk memepercepat proses pembelajaran masyarakat.

Pemanfaatan media di era digital ini dapat dijadikan sebagai strategi komunikasi. Dimana penyuluh telah mencoba menyusun pesan komunikasinya sebagai materi dengan berbagai media baik secara tradisional maupun modern. Oleh karena itu perubahan media yang digunakan merupakan strategi yang diterapkan penyuluh dalam berbagai program. Salah satu program pembangunan 
pertanian saat ini adalah penerapan sistem jajar legowo dimana masih dijadikan sebagai suatu inovasi di daerah lain. Untuk mewujudkan keberhasilan petani dalam tindakan dan peningkatan produksi usahatani padi maka menarik dilihat dari sisi persepsi petani terhadap strategi komunikasi penyuluh dalam pemanfaatan media informasidi era digital.

\section{METODE PENELITIAN}

Penelitian ini dilaksanakan di Desa Sirah Pulau Padang Kabupaten Ogan Komering Ilir. Penentuan lokasi secara sengaja (purposive) dengan pertimbangan bahwa mayoritas penduduknya adalah petani padi, dengan menggunakan metode survey. Metode penarikan contoh secara purposive sampling terhadap 6 kelompok tani dan diambil sebanyak 30 orang petani sebagai responden. Data yang dikumpulkan terdiri dari data primer dan data sekunder. Data primer dengan cara pengamatan dan wawancara langsung dengan petani berdasarkan daftar pertanyaan. Sedangkan data sekunder diperoleh dari lembaga atau instansi yang terkait.

Data yang diperoleh di lapangan dianalisa secara tabulasi dengan perhitungan skor dan dijelaskan secara deskriptif. Tujuan pertama yaitu mengukur persepsi petani terhadap strategi komunikasi penyuluh dalam pemanfaatan media informasi, dilakukan dengan perhitungn skor. Indikator yang digunakan terdiri dari teknik komunikasi, pendekatan komunikasi, saluran komunikasi dan pesan komunikasi, setiap pertanyaan diberi skor 3 untuk tinggi, skor 2 untuk kriteria sedang, dan skor 1 untuk kriteria rendah. Rumus yang digunakan untuk membuat interval kelas sebagai berikut :

$$
\begin{aligned}
& \mathrm{NR}=\mathrm{NST}-\mathrm{NSR} \\
& \mathrm{PI}=\mathrm{NR}: \mathrm{JIK}
\end{aligned}
$$

Dimana :

$$
\begin{array}{ll}
\text { NR } & =\text { Nilai Range } \\
\text { NST } & =\text { Nilai Skor Tertinggi } \\
\text { NSR } & =\text { Nilai Skor Terendah } \\
\text { JIK } & =\text { Jumlah Interval Kelas } \\
\text { PI } & =\text { Panjang Interval }
\end{array}
$$

Berdasarkan perhitungan maka interval kelas untuk mengukur persepsi petani terhadap strategi komunikasi penyuluh dapat dilihat pada Tabel 1.

Tabel 1 Nilai interval persepsi petani terhadap strategi komunikasi penyuluh

\begin{tabular}{cccc}
\hline $\begin{array}{c}\text { Nilai Interval } \\
\text { (skor total) }\end{array}$ & $\begin{array}{c}\text { Nilai Interval } \\
\text { (per indikator) }\end{array}$ & $\begin{array}{c}\text { Nilai Interval } \\
\text { (per pertanyaan) }\end{array}$ & Kriteria \\
\hline $9,00 \leq \mathrm{x} \leq 18,00$ & $3,00 \leq \mathrm{x} \leq 5,00$ & $1,00 \leq \mathrm{x} \leq 1,67$ & Rendah \\
$8,00<\mathrm{x} \leq 27,00$ & $5,00<\mathrm{x} \leq 7,00$ & $1,67<\mathrm{x} \leq 2,34$ & Sedang \\
$27,00<\mathrm{x} \leq 36,00$ & $7,00<\mathrm{x} \leq 9,00$ & $2,34<\mathrm{x} \leq 3,00$ & Tinggi \\
\hline
\end{tabular}

Tujuan kedua yaitu mengukur tindakan komunikasi petani dalam penerapan budidaya padi sistem jajar legowo sebagai penunjang ketahanan pangan dilakukan dengan mengggunakan perhitungan skor. Indikator yang digunakan terdiri dari persemaian, pengolahan tanah, penanaman, pemupukan, pemeliharaan, dan panen. Berdasarkan perhitungan maka interval kelas untuk mengukur tindakan komunikasi petani dalam budidaya padi dapat dilihat pada Tabel 2. 
Tabel 2 Nilai interval tindakan komunikasi petani dalam penerapan budidaya padi

\begin{tabular}{cccc}
\hline $\begin{array}{c}\text { Nilai Interval } \\
\text { (skor total) }\end{array}$ & $\begin{array}{c}\text { Nilai Interval } \\
\text { (per indikator) }\end{array}$ & $\begin{array}{c}\text { Nilai Interval } \\
\text { (per pertanyaan) }\end{array}$ & Kriteria \\
\hline $12,00 \leq \mathrm{x} \leq 20,00$ & $2,00 \leq \mathrm{x} \leq 3,33$ & $1,00 \leq \mathrm{x} \leq 1,67$ & Rendah \\
$20,00<\mathrm{x} \leq 28,00$ & $3,33<\mathrm{x} \leq 4,67$ & $1,67<\mathrm{x} \leq 2,34$ & Sedang \\
$28,00<\mathrm{x} \leq 36,00$ & $4,67<\mathrm{x} \leq 6,00$ & $2,34<\mathrm{x} \leq 3,00$ & Tinggi \\
\hline
\end{tabular}

\section{HASIL DAN PEMBAHASAN}

\section{Karakteristik Petani}

Karakteristik petani dalam penelitian ini digolongkan berdasarkan umur, tingkat pendidikan, pemgalaman berusahatani dan luas lahan.

\section{Umur}

Berdasarkan kategori umur petani dalam penelitian ini sangat beragam mulai dari 30 tahun hingga 67 tahun. Umur petani diklasifikasikan berdasarkan 3 kategori umur yaitu muda (30-42 tahun), dewasa (43-55 tahun) dan tua (55-68 tahun). Untuk lebih jelas mengenai pengelompokkan petani berdasarkan umur dapat dilihat pada Tabel 3.

Tabel 3 Kategori karakteristik petani di Desa Sirah Pulau Padang, Kabupaten Ogan Komering Ilir

\begin{tabular}{ccc}
\hline Kategori & Jumlah (orang) & Persentase (\%) \\
\hline Umur (tahun) & 13 & 43,33 \\
$30-42$ & 7 & 23,33 \\
$43-55$ & 10 & 33,33 \\
$55-68$ & & \\
Pendidikan & 22 & 73,33 \\
SD & 5 & 16,67 \\
SMP & 3 & 10,00 \\
SMA & 10 & 33,33 \\
Luas Lahan (Ha) & 18 & 60,00 \\
1 & 2 & 6,67 \\
2 & & \\
3 & 20 & 66,67 \\
Pengalaman (tahun) & 9 & 30,00 \\
$5-10$ & 1 & 3,33 \\
$11-16$ & & \\
$17-22$ & &
\end{tabular}

Berdasarkan Tabel 3 dapat dilihat bahwa petani berada pada umur produktif yaitu antara 30 - 64 tahun.Hanya ada dua orang responden yang berada pada umur 67 tahun yang termasuk pada umur tidak produktif. Oleh karena itu, dapat dikatakan bahwa secara fisik petani mampu mengelola usahataninya dengan baik sehingga dapat meningkatkan produksi padi yang berimplikasi pada meningkatnya penghasilan. Sebagian besar petani di Desa Sirah Pulau Padang berada pada kategori umur muda yaitu 30-42 tahun sebanyak 43,33 persen.

\section{Pendidikan}

Pendidikan merupakan faktor penting untuk mengetahui tingkat kemampuan sumberdaya manusia. Semakin tinggi tingkat pendidikan petani maka akan 
semakin rasional pola berfikirnya dan daya nalarnya. Pendidikan merupakan salah satu sarana belajar untuk meningkatkan pengetahuan, yang selanjutnya akan menanamkan pengertian sikap dan kemampuan untuk bertindak. Tingkat pendidikan petani di Desa Sirah Pulau Padang Kabupaten Ogan Komering Ilir terdiri dari tamatan Sekolah Dasar (SD), Sekolah Menengah Pertama (SMP) dan tamatan Sekolah Menengah Atas (SMA). Persentase tingkat pendidikan petani dapat dilihat pada Tabel 3.

Berdasarkan Tabel 3 dapat dilihat bahwa tingkat pendidikan petani yang melakukan budidaya padi di Desa Sirah Pulau Padang Kabupaten Ogan Komering Ilir termasuk rendah. Hal ini ditunjukkan dengan tingginya persentase tamatan Sekolah Dasar (SD) sebanyak 22 orang atau 73,33 persen, untuk tamatan Sekolah Menengah Pertama sebanyak 5 orang atau 16,67 persen. Sedangkan tamatan yang paling sedikit adalah tamatan Sekolah Menengah Atas (SMA) sebanyak 3 orang atau 10,00 persen. Semakin mudanya umur petani dan rendahnya tingkat pendidikan akan mempengaruhi pola keputusan petani dalam mengadopsi inovasi. Hal ini sejalan dengan hasil penelitian Asih (2009) menyatakan bahwa umur muda dengan tingkat pendidikan yang tinggi memungkinkan petani lebih dinamis dan lebih cepat menerima inovasi dalam mengelola usahatani.

\section{Luas lahan}

Luas lahan yang diusahakan oleh petani di Desa Sirah Pulau Padang sangat bervariasi berkisar 1 sampai dengan 3 hektar. Berdasarkan Tabel 3, dapat dilihat bahwa lahan yang dimiliki petani padi di Desa Sirah Pulau Padang paling banyak dengan luas lahan $2 \mathrm{Ha}$ yaitu sebanyal 60 persen. Selain itu, luas lahan petani 1 Ha yaitu sebanyak 10 orang atau 33,33 persen sedangkan petani padi yang memiliki luas lahan $3 \mathrm{Ha}$ hanya 2 orang petani atau 6,67 persen. Hal ini menunjukkan bahwa lahan yang dimiliki petani cukup luas karena usahatani padi sebagai pekerjaan utama petani setempat. Lahan di daerah tersebut termasuk lahan sawah lebak yang kebanyakan merupakan warisan orang tua, selain itu lahan tersebut dari sisi harga jual termasuk relatif lebih murah dibandingkan lahan kering.

\section{Pengalaman usahatani}

Pengalaman usahatani merupakan salah satu faktor yang mempengaruhi keberhasilan dalam budidaya padi. Dengan belajar dari pengalaman, petani akan mendapatkan pengetahuan baik teori maupun praktek untuk memperlancar kegiatan usahataninya. Petani yang sudah lama bertani tentunya akan mempunyai persepsi yang berbeda dari pada petani yang baru terjun dalam usahatani padi. Petani yang sudah lama bertani lebih mudah menerapkan inovasi dari pada petani baru, karena pengalaman yang lebih banyak sehingga dapat membuat perbandingan dalam mengambil keputusan.

Berdasarkan Tabel 3 dapat dilihat bahwa sebagian besar petani padi di Desa Sirah Pulau Padang memiliki pengalaman usahatani padi relatif baru yaitu berkisar 5-10 tahun sebanyak 66,67 persen atau berjumlah 20 orang. Selain itu, petani yang memiliki pengalaman berusahatani dengan kategori sedang (11-16 tahun), sebanyak 30,00 persen dengan jumlah 9 orang petani dan pengalaman usahatani yang termasuk kategori lama (17-22 tahun) sebanyak 3,33 persen atau hanya 1 orang petani saja. 


\section{Persepsi Petani terhadap Strategi Komunikasi Penyuluh dalam Pemanfaatan Media Informasi}

Persepsi petani diartikan sebagai pengalaman seseorang tentang obyek, peristiwa, atau hubungan-hubungan yang diperoleh dengan menyimpulkan informasi dan menafsirkan pesan (Rakhmat, 2004). Strategi komunikasi adalah metode penyuluh dalam melakukan aktivitas komunikasinya kepada petani dengan memanfaatkan media informasi yang ada. Penyuluh terfokus pada strategi komunikasi yang meliputi teknik komunikasi, pendekatan komunikasi, saluran komunikasi dan pesan komunikasi. Adapaun indikator persepsi petani terhadap strategi komunikasi penyuluh dapat dilihat sebagai berikut:

\section{Teknik komunikasi}

Teknik komunikasi merupakan cara penyampaian informasi kepada petani secara efektif sehingga mampu tepat mengenai sasaran. Teknik komunikasi dalam strategi komunikasi yang digunakan penyuluh dilihat dari cara penyampaian pesan, teknik penyampaian pesan dan penggunaan bahasa, secara rinci dapat dilihat pada Tabel 4 .

Tabel 4 Skor rata-rata teknik komunikasi penyuluh di Desa Sirah Pulau Padang, Kabupaten OKI

\begin{tabular}{lcc}
\hline Komponen Indikator & Skor Rata-rata & Kriteria \\
\hline - Cara penyampaian pesan & 2,47 & Tinggi \\
- Teknik penyampaian pesan & 2,50 & Tinggi \\
- Penggunaan bahasa & 2,53 & Tinggi \\
\hline Jumlah & 7,50 & Tinggi \\
\hline
\end{tabular}

Komponen strategi komunikasi penyuluh dalam teknik komunikasi yang dilihat dari cara penyampaian pesan dengan skor rata-rata 2,47 berada pada kriteria tinggi. Hal ini menunjukkan bahwa petani menyetujui cara penyampaian yang dilakukan oleh penyuluh dengan menggunakan komunikasi interpersonal yaitu cara perorangan dan cara kelompok. Cara perorangan yang dilakukan oleh penyuluh termasuk komunikasi interpersonal dimana dinyatakan oleh Oktarina dkk (2010) interaksi dengan petani lain yang berada di dalam dan di luar kelompok wanita tani, merupakan salah satu bentuk komunikasi interpersonal selain itu juga interaksi dengan PPL dan interaksi dengan aparat desa. Berbeda dengan teknik komunikasi secara kelompok dimana petani dikumpulkan dalam pertemuan untuk berdiskusi. Menurut Van Den Ban \& Hawkins (1999)menyatakan bahwa pada diskusi kelompok penyuluh dapat berinteraksi langsung dengan petani maupun sesama petani dimana penyuluhan dapat disesuaikan dengan kebutuhan dan tingkat pengetahuan petani.

Untuk komponen teknik penyampaian pesan mendapatkan skor rata-rata 2,50 dengan kriteria tinggi. Hal ini berarti bahwa petani mengerti terhadap pesan yang disampaikan penyuluh. Teknik penyampaian yang dilakukan melalui penyuluhan yaitu ceramah dan terkadang langsung praktek berupa peragaan. Van Den Ban \& Hawkins (1999) menyatakan bahwa ceramah merupakan salah satu sarana penting untuk mengalihkan informasi dalam penyuluhan. Kemudian untuk komponen penggunaan bahasa juga berada pada kriteria tinggi dengan skor ratarata 2,53, artinya petani mengerti dan memahami bahasa yang digunakan penyuluh dalam menyampaikan pesan. Dalam hal ini, meskipun penyuluh bukan 
penduduk lokal, tetapi penyuluh dapat menggunakan dan mengerti bahasa lokal petani sehingga petani lebih mudah dalam menerima pesan. Penelitian ini diperkuat oleh hasil penelitian Wibowo dkk (2018) yang menyatakan bahwa agar petani dan anggota gapoktan mudah mengerti terhadap pesan yang disampaikan oleh petugas penyuluh pertanian lapangan (PPL) maka hendaknya lebih dominan menggunakan bahasa daerah setempat.

\section{Pendekatan komunikasi}

Pengukuran strategi komunikasi dalam pendekatan komunikasi dapat dilihat dari komponen keaktifan penyuluh, frekuensi kehadiran penyuluh dan kedekatan penyuluh terhadap petani. Pengukuran skor dalam pendekatan komunikasi dapat dilihat pada Tabel 5.

Tabel 5 Skor rata-rata pendekatan komunikasi penyuluh di Desa Sirah Pulau Padang, Kabupaten OKI

\begin{tabular}{lcc}
\hline Komponen Indikator & Skor & Kriteria \\
\hline - Keaktifan penyuluh & 2,43 & Tinggi \\
- Frekuensi kehadiran penyuluh & 2,40 & Tinggi \\
- Kedekatan penyuluh & 1,97 & Sedang \\
\hline Jumlah & 6,80 & Sedang \\
\hline
\end{tabular}

Pendekatan komunikasi penyuluh menunjukkan skor rata-rata 6,80 yang termasuk pada kriteria sedang. Dilihat dari keaktifan penyuluh mendapatkan skor rata-rata 2,43 dengan kriteria tinggi. Hal ini berarti bahwa petani mendapat perhatian dari penyuluh karena penyuluh selalu hadir pada saat proses penerapan atau praktek yang telah diajarkan oleh penyuluh untuk memakai sistem jajar legowo. Selain itu, petani selalu datang pada saat dibutuhkan petani. Untuk komponen frekuensi kehadiran penyuluh mendapatkan skor rata-rata 2,40 dengan kriteria tinggi. Artinya penyuluh melakukan kunjungan tiga kali selama musim tanam berlangsung. Kemudian untuk komponen kedekatan penyuluh terhadap petani juga berada pada kriteria sedang dengan skor rata-rata 1,97. Artinya petani merasa dekat secara emosional terhadap penyuluh merasa tidak canggung untuk menyampaikan keluhan tentang hambatan yang dialami dalam berusahatani padi dengan sistem jajar legowo ini. Hal ini sesuai dengan hasil penelitian Aryani dkk (2014) yang menyatakan bahwa pentingnya peran penyuluh pertanian dalam memberikan arahan dan masukan-masukan kepada petani.

\section{Saluran komunikasi}

Pengukuran strategi komunikasi terhadap saluran komunikasi terdiri dari perorangan dan kelompok, keterlibatan petani dalam menyusun materi, dan adanya perubahan pada petani. Penilaian skor respon petani dalam saluran dalam strategi komunikasi yang dilakukan oleh penyuluh pertanian lapangan dapat dilihat dalam Tabel 6.

Tabel 6 Skor rata-rata saluran komunikasi di Desa Sirah Pulau Padang, Kabupaten OKI

\begin{tabular}{lcc}
\hline Komponen Indikator & Skor & Kriteria \\
\hline - Bentuk media komunikasi & 2,37 & Tinggi \\
- Pemanfaatan media komunikasi & 2,33 & Sedang \\
- Pemanfaatan sumber informasi lainnya & 2,27 & Sedang \\
\hline Jumlah & 6,97 & Sedang \\
\hline
\end{tabular}


Komponen strategi komunikasi Penyuluh Pertanian Lapangan dalam saluran komunikasi yang dilihat dari bentuk media komunikasi berada pada skor rata-rata 2,37 dengan kriteria tinggi. Hal ini berarti petani setuju dengan bentuk media komunikasi yang dilakukan oleh penyuluh yaitu dengan menggunakan media cetak dan elektronik. Hal ini disebabkan karena media cetak dan elektronik dianggap lebih mudah bagi petani dalam menambah pengetahun tentang cara berusahatani dengan sistem jajar legowo.

Untuk komponen dalam pemanfaatan media informasi berada pada skor rata-rata 2,33 dengan kriteria sedang. Hal ini berarti penyuluh dalam merancang atau menyusun pesan yang akan di sampaikan kepada petani memanfaatkan berbagai media mulai dari radio, koran dan internet. Selain itu, penyuluh sekalisekali mengajak menonton cara petani di daerah lain dalam melakukan budidaya padi sistem jajar legowo melalui video atau youtube. Untuk mempermudah komunikasi lainnya, penyuluh juga bisa membuat grup dengan memanfaatkan media facebook dan whatsapp. Oleh karena itu, penyuluh lebih cenderung memanfaatkan media yang ada dalam diseminasi inovasi. Berdasarkan temuan Far-Far (2011) menyatakan bahwa sebagian besar petani lebih banyak memanfaatkan komunikasi interpersonal dibandingkan media massa dalam mencari informasi. Hal ini terkait umunya petani memiliki tingkat pengetahuan relatif rendah.

Kemudian untuk komponen pemanfaatan sumber informasi lainnya berada pada kriteria sedang dengan skor rata-rata 2,27. Hal ini berarti bahwa petani memiliki persepsi bahwa penyuluh juga berbagi informasi (bertukar pikiran) tentang cara berusahatani dengan teman sesama penyuluh dan orang dari berbagai instansi. Hal ini seiring dengan hasil penelitian Prihlanti dkk (2007) yang menyatakan bahwa media informasi yang dianggap paling bermanfaat adalah teman, keluarga dan PPL dalam memperoleh tahapan informasi dalam usahatani.

\section{Pesan komunikasi}

Pengukuran strategi komunikasi dalam pesan komunikasi dapat dilihat dari komponen indikator kesesuaian pesan dengan kebutuhan petani, jenis pesan dan pesan lain selain jajar legowo. Skor persepsi petani terhadap pesan komunikasi dalam aktivitas komunikasi dapat dilihat dalam Tabel 7.

Tabel 7 Skor rata-rata pesan komunikasi di Desa Sirah Pulau Padang, Kabupaten OKI

\begin{tabular}{lll}
\hline Komponen Indikator & Skor & Kriteria \\
\hline - Kesesuaian pesan dengan kebutuhan petani & 2,17 & Sedang \\
- Jenis pesan & 2,30 & Sedang \\
- Pesan lain selain jajar legowo & 2,27 & Sedang \\
\hline Jumlah & 6,73 & Sedang \\
\hline
\end{tabular}

Komponen pesan komunikasi yang dilihat dari kesesuaian pesan yang disampaikan dengan kebutuhan petani berada pada skor 2,17 dengan kriteria sedang. Hal ini menunjukkan bahwa pesan yang disampaikan oleh penyuluh kepada petani belum begitu sesuai dengan yang diinginkan petani. Hal ini disebabkan penyuluh juga membawa pesan sesuai program yang harus ditransfer kepada petani. Untuk komponen jenis pesan yang disampaikan berada pada skor rata-rata 2,30 dengan kriteria sedang. Artinya penyuluh menyampaikan jenis pesan kepada petani hanya bersifat budidaya padi saja yaitu mulai dari persiapan 
lahan sampai panen. Padahal dari segi teknik budidaya, petani mengganggap mereka lebih pintar karena hal yang digeluti setiap harinya. Kemudian untuk komponen pesan lain selain materi jajar legowo berada pada kriteria sedang dengan skor rata-rata 2,27. Hal ini menunjukkan bahwa penyuluh jarang sekali menyampaikan materi di luar jajar legowo karena penyuluh terfokus untuk membekali petani dengan sistem jajar legowo agar usahatani padi yang diterapkan berhasil dan sesuai dengan yang diharapkan. Meskipun demikian, apabila petani bertanya maka penyuluh selalu membantu memberikan solusinya.

Hasil pengukuran dari empat indikator tersebut menunjukkan bahwa persepsi petani terhadap strategi komunikasi penyuluh berada pada kriteria tinggi. Adapun strategi komunikasi penyuluhan pertanian dapat dilihat pada Tabel 8.

Tabel 8 Skor total rata-rata persepsi petani terhadap strategi komunikasi penyuluh di Desa Sirah Pulau Padang, Kabupaten OKI

\begin{tabular}{|c|c|c|}
\hline Komponen Indikator & Skor & Kriteria \\
\hline - Teknik Komunikasi & 7,50 & Tinggi \\
\hline - Pendekatan Komunikasi & 6,80 & Sedang \\
\hline - Saluran Komunikasi & 6,97 & Sedang \\
\hline - Pesan Komunikasi & 6,73 & Sedang \\
\hline Jumlah & 28,00 & Tinggi \\
\hline
\end{tabular}

Berdasarkan Tabel 8 diperoleh jumlah skor rata-rata persepsi petani terhadap strategi komunikasi penyuluh adalah 28,00 yang termasuk dalam kriteria sedang. Hal ini menunjukkan bahwa petani berpersepsi positif terhadap strategi komunikasi yang digunakan oleh penyuluh dalam menyampaikan pesan kepada petani maupun pemanfaatan media informasi yang dikemas dengan baik sehingga dapat diterima dan dimengerti oleh petani.

\section{Tindakan Komunikasi Petani dalam Penerapan Budidaya Padi Sistem Jajar Legowo sebagai Penunjang Ketahanan Pangan}

Ketahanan pangan meliputi ketersediaan, distribusi dan konsumsi yang tidak terlepas dari tindakan petani dalam melakukan budidaya padi. Tindakan komunikasi petani tersebut merupakan salah satu upaya penunjang ketahanan pangan dari sisi ketersediaan pangan khusunya komoditi beras. Petani yang memiliki tindakan komunikasi yang baik dianggap petani yang mau menerapkan sesuai anjuran penyuluh. Tindakan petani adalah keterampilan yang dilakukan petani dalam menerapkan budidaya padi sistem jajar legowo mulai dari persemaian sampai panen. Pengukuran komponen tindakan komunikasi petani meliputi persemaian, pengolahan tanah, penanaman, pemupukan, pengendalian gulma, pengendalian hama dan penyakit, dan panen. Untuk lebih jelas mengenai pengukuran tindakan komunikasi petani dapat dilihat pada Tabel 9.

Tabel 9 Skor rata-rata tindakan komunikasi petani padi di Desa Sirah Pulau Padang Kabupaten OKI.

\begin{tabular}{clcc}
\hline No & Keterampilan Petani & Skor & Kriteria \\
\hline 1 & Persemaian & 5,60 & Tinggi \\
2 & Pengolahan tanah & 5,33 & Tinggi \\
3 & Penanaman & 5,47 & Tinggi \\
4 & Pemupukan & 5,07 & Tinggi \\
5 & Pengendalian hama dan penyakit & 5,03 & Tinggi \\
6 & Panen & 4,83 & Tinggi \\
\hline & Jumlah & 31,33 & Tinggi \\
\hline
\end{tabular}


Tabel 9 menunjukkan tindakan komunikasi petani padi di Desa Sirah Pulau Padang Kabupaten Ogan Komering Ilir didapat masing-masing skor rata-rata petani tergolong tinggi dengan jumlah skor 31,33. Hal Ini berarti petani memiliki keterampilan yang baik dalam pembudidayaan padi, dimana mereka cenderung menerapkan pengetahuan dalam budidaya padi secara turun temurun. Persemaian dilakukan pada lahan yang sama atau berdekatan dengan petakan sawah yang akan ditanami. Persemaian yang biasa dilakukan petani berupa pesemaian darat yang memanfaatkan pematang di sekitar sawah. Pada indikator persemaian, skor rata-rata 5,60 yang tergolong dalam kriteria tinggi.

Pengolahan tanah menunjukkan skor rata-rata 5,33 yang termasuk dalam kriteria tinggi. Pada saat pengolahan tanah, petani membajak atau mencangkulnya, dilanjutkan dengan penanaman. Pengolahan tanah dilakukan 1-2 bulan sebelum tanam, tetapi ada juga petani yang melakukan pengolahan tanah kurang dari 1-2 bulan sebelum tanam. Indikator penanaman menunjukkan skor rata-rata 5,47 yang termasuk dalam kriteria tinggi. Dalam hal ini, padi yang ditanam oleh petani ditanam dengan sisitem jajar legowo dengan tipe 2:1 adalah $25 \mathrm{~cm}$ (jarak antar barisan) x $15 \mathrm{~cm}$ (jarak dalam barisan) x $50 \mathrm{~cm}$ (jarak lorong). Penanaman dilakukan dengan cara memindahkan bibit dari tempat semai. Cara menanam bibit padi dengan cara berjalan mundur dengan tangan kiri memegang bibit, tangan kanan menanam dengan kedalaman $5-10 \mathrm{~cm}$, tetapi ada juga petani yang menanam dengan kedalaman kurang dari 5-10 cm.

Pemupukan menunjukkan skor rata-rata 5,07 yang tergolong dalam kriteria tinggi. Dalam hal ini pemupukan tetap dilakukan dengan beberapa tahapan. Tahapan yang pertama, pupuk dasar yaitu dengan memberi pupuk pada media persemaian. Pemupukan tahapan kedua, dilakukan setelah penanaman. Pemupukan tahapan ketiga, dilakukan pada waktu \pm 60 hari setelah tanam, pupuk ditaburkan pada bibit padi. Pupuk yang digunakan adalah pupuk alami misalnya pupuk kandang, pupuk kompos atau pupuk organik cair (POC) sebagai pupuk dasar sebelum bibit padi ditanam. Hanya sebagian kecil petani yang tidak melakukan pemupukan karena alas an ekonomi. Pengendalian hama dan penyakit menunjukkan skor rata-rata 5,03 yang menunjukkan tergolong dalam kriteria tinggi. Dalam hal ini petani melakukan pengendalian hama dan penyakit dengan cara manual dan kimia yaitu pengendalian serangan tikus dengan cara gropyokan dan pengemposan atau dengan rodensida.

Indikator panen menunjukkan skor rata-rata 4,83 yang menunjukkan kriteria tinggi. Dalam hal ini petani melakukan panen tepat waktu dengan menggunakan sabit dan menyisakan batang setinggi $30 \mathrm{~cm}$, tetapi ada juga petani yang menyisakan batang kurang dari $30 \mathrm{~cm}$. komponen keterampilan petani dengan skor 31,33 yang termasuk ke dalam kriteria tinggi, hal ini menunjukkan bahwa indikator tindakan komunikasi petani padi di Desa Sirah Pulau Padang Kabupaten Ogan Komering Ilir yang meliputi persemaian, pengolahan tanah, penanaman, pemupukan, pengendalian hama dan penyakit serta panen sudah sesuai dengan apa yang di harapkan oleh petani dan penyuluh.

\section{KESIMPULAN DAN SARAN}

Petani memiliki persepsi positif terhadap strategi komunikasi penyuluh dalam pemanfaatan informasi yang dilihat dari teknik komunikasi, pendekatan komunikasi, saluran komunikasi dan pesan komunikasi. Persepsi petani berada pada kriteria sedang dimana penyuluh telah cukup baik dalam melakukan aktivitas 
komunikasinya. Tindakan komunikasi petani dalam budidaya padi termasuk dalam kriteria tinggi dimana mereka tertarik dan menerapkan sistem budidaya jajar legowo.

\section{DAFTAR PUSTAKA}

Aryani D, S Oktarina, H Malini. 2014. Pola Usahatani, Pendapatan dan Ketahanan Pangan Rumah Tangga Petani Padi Lahan Rawa Lebak di Sumatera Selatan. Prosiding Seminar Nasional Lahan Suboptimal 2014, Palembang 26-27 September 2014 ISBN: 979-587-529-9 p: 462-471.

Asih, DN. 2009. Analisis Karakteristik dan Tingkat Pendapatan Usahatani Bawang Merah Di Sulawesi Tengah. Jurnal Agroland, Vol 16(1): 53-59.

Dewan Ketahanan Pangan. 2006. Kebijakan Umum Ketahanan Pangan 20062009. Jurnal Gizi dan Pangan, Vol 1(1): 57-63.

Far-Far, RA. 2011. Pemanfaatan Sumber Informasi Usahatani Oleh Petani Sayuran Di Desa Waiheru Kota Ambon. Jurnal Ilmiah agribisnis dan Perikanan (agrikan UMMU-Ternate), Vol 4(1): 38-46.

Oktarina S, M. Hamzah, Y Junaidi. 2010. Peran Komunikasi Dalam Pemberdayaan Kelompok Wanita Tani Pada Usahatani Padi Di Daerah Transmigrasi Provinsi Sumatera Selatan. Prosiding Seminar Nasional Hasil Penelttian Bidang Pertanian, Palembang 20-21 Oktober 2010.ISBN : 978 979-25-8651-0, p: 162-182.

Prihlanti TM, Maria, Yuliawati. 2007. Persepsi Petani terhadap Informasi Pertanian. Jurnal Agric, Vol 19 (1\&2): 44-57.

Rakhmat J. 2004. Psikologi Komunikasi. Rosdakarya. Bandung.

Sumardjo, L.M. Baga, R.S.H. Mulyandari. 2010. Cyber Extension : Peluang dan Tantangan dalam Revitalisasi Penyuluhan Pertanian. IPB Press. Bogor.

Suwignyo A, F Zulvica, Herdinsyah. 2008. Adaptasi Teknologi Produksi Padi Di Lahan Rawa Lebak: Upaya Menghindari Pengaruh Negatif Terendamnya Tanaman Padi Melalui Pengaturan Aplikasi Pupuk Nitrogen. Seminar Nasional Padi. Sukamandi. P: 1237-1244. | Request PDF. Available from: https://www.researchgate.net/publication/277773309_ADAPTASI_TEKNO LOGI_PRODUKSI_PADI_DI_LAHAN_RAWA_LEBAK_UPAYA_MEN GHINDARI_PENGARUH_NEGATIF_TERENDAMNYA_TANAMAN_P ADI_MELALUI_PENGATURAN_APLIKASI_PUPUK_NITROGEN [accessed Sep 22 2018].

Van Den Ban AW, HS Hawkins. 1999. Penyuluhan Pertanian. Kanisius. Yogyakarta.

Wibowo HS, N Sutjipta, IW Windia. 2018. Peranan Penyuluh Pertanian Lapangan (PPL) sebagai Fasilitator dalam Penggunaan Metode Belajar Pendidikan Orang Dewasa (Andragogi) (Kasus di Gapoktan Madani, Desa Sampalan Klod, Kecamatan Dawan, Kabupaten Klungkung, Provinsi Bali). E-Jurnal Agribisnis dan Agrowisata, Vol7(1):21-3 